\title{
ALIAKSANDR PAHARELY
}

ORCID: 0000-0003-2182-6656

\section{CZYNNIKI SPOŁECZNO-KULTUROWE KSZTAŁTOWANIA SIE „WSPÓLNOTY MORALNEJ” W ŚWIETLE PRASY BIALORUSKIEJ CHRZEŚCIJAŃSKIEJ DEMOKRACJI OKRESU MIĘDZYWOJENNEGO ${ }^{1}$}

DOI: $10.15290 /$ sp.2021.29.12

Białoruska Chrześcijańska Demokracja (od 1936 r. - Białoruskie Zjednoczenie Narodowe) została założona w maju 1917 r. przez grupę katolickich księży-Białorusinów i świeckich Białorusinów-katolików w Piotrogrodzie jako Zjednoczenie Chrześcijańsko-Demokratyczne (na początku jako ChDZ „Chrześcijańsko-Demokratyczny Związek”, od 1926 r. „Białoruska Chrześcijańska Demokracja”). To stronnictwo polityczne odegrało olbrzymią rolę w tworzeniu nowoczesnej białoruskiej kultury politycznej, struktur społeczeństwa obywatelskiego, w dialogu międzywyznaniowym i propagowaniu nowoczesnej tożsamości narodowej białoruskiej wśród chłopów.

Od początku historii $\mathrm{BChD}$ prasa odgrywała kluczową rolę nie tylko w upowszechnianiu ideologii chrześcijańsko-demokratycznej, ale także w kształtowaniu opinii publicznej i inspirowaniu udziału chłopów w polityce i procesach modernizacji.

Do organów prasowych BChD obok gazety „Krynica” (w latach 1925-1937 „Biełaruskaja Krynica”) należały również czasopisma: „Chryścijanskaja Dumka” (1928-1939), „Samapomacz” (1932-1939), „Szlach Moładzi” (1929-1939), „Szlach biełaruskaha studenta” (dodatek do „Szlachu Moładzi”, 1938-1939).

1 Autoreferat rozprawy doktorskiej obronionej na Wydziale Historii i Stosunków Międzynarodowych Uniwersytetu w Białymstoku w dniu 6 maja 2021 r. Promotorem pracy był dr hab. Aliaksandr Smalianchuk (Instytut Slawistyki Polskiej Akademii Nauk w Warszawie), zaś recenzentami dr hab. Piotr Cichoracki (Uniwersytet Wrocławski) i dr hab. Jerzy Grzybowski (Uniwersytet Warszawski). 
Wszystkie były wydawane w Wilnie w języku białoruskim zapisywanym zarówno alfabetem łacińskim, jak i cyrylicą.

Czynniki społeczno-kulturowe w prasie BChD-BZN odgrywały zasadniczą rolę w rozpowszechnianiu nowych wartości w środowisku białoruskich chłopów. Przyjmując te wartości, chłopi powinni stać się nowocześni, co utożsamiało ich ze „wspólnotą moralną”.

Pojęcie nowoczesności w niniejszej rozprawie można scharakteryzować nie tyle jako nadejście państwa narodowego, demokracji i kapitalizmu rynkowego, zgodnie z tezą Barringtona Moore’a Jr., ile idealny stan, w którym wartości związane z czynnikami społeczno-kulturowymi będą władać życiem społeczeństwa i wyznaczać jego priorytety.

Pod pojęciem „wspólnoty moralnej”, w ślad za amerykańską badaczką Keely Stauter-Halsted, w niniejszej rozprawie doktorskiej rozumie się grupę politycznie i społecznie aktywnych Białorusinów, do której bezpośrednio należeli zwolennicy ideologii i członkowie Białoruskiej Chrześcijańskiej Demokracji na wsi, a pośrednio także inni Białorusini zaangażowani w życie polityczne, społeczne i gospodarcze, czytający prasę $\mathrm{BChD}-\mathrm{BZN}$. Jest to wspólnota oparta na kryteriach moralnych, jednocząca intelektualistów, polityków i nową kadrę wiejskich działaczy.

„Wspólnota moralna” nie stanowi wspólnoty narodowej sensu stricto, ponieważ nie wystarczy być przedstawicielem danej narodowości, aby w niej uczestniczyć. Ta kategoria obejmowała politycznie aktywne, działające jednostki i grupy, a nie bierne masy, mimo że ich narodowość nie ulegała wątpliwości zarówno z punktu widzenia językowego, jak w kategoriach biologicznych. Członków takiej wspólnoty przeciwstawiano grupie „ciemnych”, niewykształconych mieszkańców wsi, „pijaków”, miłośników gry w karty itd. Aby mogli oni włączyć się do tej wspólnoty, powinni podjąć odpowiednie działania: na przykład czytać białoruską prasę (przede wszystkim prasę $\mathrm{BChD}$ ), angażować się $\mathrm{w}$ działalność białoruskich stowarzyszeń, organizować kooperatywy itd.

Rozwój moralny dokonywał się poprzez utwierdzenie się w swoich przekonaniach i dobrowolne uświadomienie, a także naśladowanie „dobrego przykładu" propagowanego w prasie. Przy tym, jak dowodzi niniejsza rozprawa, wspólnota realizowała się na dwóch poziomach: pierwszy poziom stanowili ci, którzy faktycznie brali w niej udział jako „sprawujący władzę nad procesem tworzenia dyskursu", ale na drugim poziomie obejmowała także ten sam krytykowany „ciemny lud”, który mógł dołączyć do wspólnoty, jej potencjalnych członków. Wspólnota pozostawała dla nich otwarta. Różnica między tymi grupami polegała na samodyscyplinie społecznej. 
Zasadniczym celem niniejszej rozprawy doktorskiej było określenie roli czynników społeczno-kulturowych (reguł zachowania się w sferze publicznej, dyscypliny czasu, stosunku do miasta, pielęgnowania i zachowania selektywnie wybranych elementów kultury wiejskiej jako symboli etnicznych) na łamach organów prasowych Białoruskiej Chrześcijańskiej Demokracji w kształtowaniu się „,wspólnoty moralnej”, a także wskazanie sprzeczności i przeszkód, które towarzyszyły temu procesowi.

Prasa międzywojennej BChD-BZN występuje w tej pracy jako kluczowe źródło, a przedmiotem badań jest jej dyskurs. Obiekt badań stanowią odzwierciedlone na łamach tej prasy czynniki społeczno-kulturowe.

Przy tym autor dążył do odpowiedzi na następujące pytania: jakie były reguły udziału w sferze publicznej, cechy ewolucyjnego programu transformacji społecznej; w jaki sposób artykułowano rolę dyscypliny czasu, jaki był stosunek wobec miasta; $w$ jaki sposób wyrażała się przemiana elementów kultury ludowej w symbole etniczne; kto określał się jako „swój” i jako członek „wspólnoty moralnej" i w jaki sposób znajdowała swój wyraz kwestia rozumienia chłopstwa jako klasy w prasie BChD-BZN?

W niniejszej rozprawie wykazano, że w prasie Białoruskiej Chrześcijańskiej Demokracji funkcjonowały dwa poziomy dyskursu: pierwszy (dla którego można zapożyczyć angielski termin high brow), skierowany do lepiej wykształconego czytelnika, orientującego się w sferze polityki, gospodarki, rolnictwa, techniki itd., znającego terminologię używaną w tych dziedzinach; i drugi (low brow) - adresowany do szerokich mas białoruskich chłopów, znajdujących się dopiero w początkowej fazie poznawania realiów współczesnego życia politycznego, społecznego i gospodarczego.

W pracy została sformułowana następującą hipoteza: czynniki społeczno-kulturowe odgrywały zasadniczą rolę w kształtowaniu się „wspólnoty moralnej” na łamach prasy BChD-BZN, a sama prasa miała większe znaczenie dla tworzenia ideologii Białoruskiej Chrześcijańskiej Demokracji niż dokumenty polityczne, programy i odezwy przywódców na forum politycznym.

Ramy chronologiczne tego badania historycznego stanowią lata 1917-1939, czyli okres między ostatnimi latami I wojny światowej i dwoma rewolucjami rosyjskimi a wybuchem II wojny światowej. To czas istnienia i funkcjonowania prasy BChD-BZN. W celu bardziej szczegółowego zbadania specyfiki powstawania i funkcjonowania prasy BChD-BZN należy jednak sięgnąć do wcześniejszego okresu - do drugiej połowy XIX i początku XX w.

Ramy geograficzne badania obejmują cztery północno-wschodnie województwa II Rzeczypospolitej: wileńskie, nowogródzkie, poleskie oraz białostockie. 
Do tych terenów odnosi się również nazwa „Zachodnia Białoruś". Jeśli w pierwszym przypadku można mówić o ogólnie przyjętych w ramach międzywojennego państwa polskiego jednostkach administracyjnych i ich nazwach, to druga nazwa była szeroko stosowana przez białoruskie partie polityczne, organizacje, a także prasę. W białoruskiej prasie chrześcijańsko-demokratycznej obok tej nazwy sporadycznie używano określenia „Wschodnia Litwa”.

Praca ma charakter badania historycznego. Opiera się przede wszystkim na wykorzystaniu metodologii nauk ogólnych (analiza i synteza, indukcja i dedukcja, analogia i modelowanie). W rozprawie doktorskiej zostały wykorzystane specjalne metody badań historycznych. Metoda historyczno-genetyczna pomogła prześledzić proces powstania prasy $\mathrm{BChD}$, a także przeanalizować zmiany kontekstu politycznego, kulturowego i ideologicznego w okresie międzywojennym. Zastosowano również metodę porównawczą (wraz z metodą diachronicznej analizy historycznej) - przy zestawieniu problematyki i sytuacji $\mathrm{BChD}$, jej prasy, jej zwolenników i czytelników na wsi z przykładami litewskimi, polskimi, ukraińskimi oraz innych ruchów narodowych i politycznych w Europie Środkowo-Wschodniej w drugiej połowie XIX i na początku XX w. Obok tych metod dla analizy materiałów prasowych wykorzystano pewne elementy krytycznej analizy dyskursu.

Ponadto w celu zrozumienia społeczno-kulturowego kontekstu problematyki zastosowano metody i osiągnięcia antropologii kulturowej. Z teorii antropologa C. Levi-Straussa zostało zapożyczone pojęcie „opozycji binarnych”. Zastosowano też ideę „wizji ograniczonych zasobów” G. Fostera. Wykorzystano również koncepcję czasu społecznego S. Hansona, opracowaną na podstawie weberowskiej typologii przywództwa. Niniejsze badanie historyczne wykorzystuje więc badania interdyscyplinarne.

Centralną koncepcją w problematyce zarysowanej przez społeczno-kulturowe czynniki w prasie $\mathrm{BChD}$-BZN jest „wizja ograniczonych zasobów” (the image of limited good), zaproponowana przez amerykańskiego antropologa George’a Fostera. Zakłada ona, że w kulturach chłopskich na nierefleksyjnym poziomie podkreślany jest ograniczony i nieznaczący charakter możliwości gospodarstwa chłopskiego i uzyskania dużego urodzaju, niewielki obszar nadziałów ziemi, niedostatek zdrowia, zasobów materialnych, przyjaźni, miłości, szacunku, statusu społecznego, roli mężczyzny. A przy tym w pojmowaniu samych chłopów nie ma możliwości zwiększenia tych zasobów. Może się to dokonać tylko kosztem innych.

Historiografię dotyczącą problemu badawczego reprezentują liczne prace postsowieckich białoruskich i polskich autorów zarówno sprzed jak i po 1989 r. 
Znalazły się w niej także badania ukraińskie i amerykańskie. Tematycznie większość prac obejmuje aspekty polityczne i religioznawcze.

Za główne źródła historyczne pracy posłużyły białoruska i polska prasa okresu międzywojennego, ukazująca się w Wilnie, dokumenty Archiwum Akt Nowych w Warszawie, Litewskiego Centralnego Archiwum Państwowego w Wilnie, Białoruskiego Państwowego Archiwum-muzeum Literatury i Sztuki w Mińsku, wspomnienia i dzienniki, materiały badań socjologicznych i antropologicznych okresu międzywojennego.

Praca składa się z wprowadzenia do tematu, sześciu rozdziałów i podsumowania.

W rozdziale pierwszym rozpatrzono zagadnienie stworzenia i funkcjonowania sfery publicznej na zachodniobiałoruskiej wsi z podkreśleniem znaczenia prasy wydawanej przez BChD-BZN. Wskazano również na politykę, gospodarkę i kulturę jako usankcjonowane obszary sfery publicznej. Przeanalizowano kwestię zasad uczestnictwa w sferze publicznej jako kryterium aktywnej przynależności do „wspólnoty moralnej” i język polityki używany w prasie - w kontekście ogólnopolitycznego dyskursu, cenzury i społeczno-kulturowej specyfiki białoruskiej wsi.

Sama próba stworzenia sfery publicznej w Zachodniej Białorusi jako istotnego instrumentu przekształcającego tradycyjne sposoby jej funkcjonowania w mechanizmy kształtowania opinii publicznej, które sprzyjałyby ewolucyjnej modernizacji wsi, była dążeniem do transformacji dyskursu wiejskiego i napełnienia go nową treścią. Oczywiście nie tylko prasa BChD-BZN działała na rzecz stworzenia sfery publicznej na wsi. Druki w innych językach i o innej orientacji ideologicznej również odegrały ważną rolę, lecz to właśnie publikacje $\mathrm{BChD}$ w tym konkretnym czasie i miejscu wystarczająco radykalnie utwierdzały białoruskich chłopów w ich podmiotowości, bez względu na zarzuty na przykład o zbytnie uleganie litewskim wpływom.

Na przestrzeni międzywojennych dekad sfera publiczna nabierała coraz bardziej symbolicznego charakteru. Zapaść legalnego białoruskiego życia politycznego, zamykanie białoruskich organizacji, z których część znajdowała się pod kontrolą BChD-BZN w Wilnie, a także presja cenzury bez wątpienia pogłębiały ten proces. Niektórzy czytelnicy rezygnowali z prenumeraty prasy $\mathrm{BChD}$ pod koniec lat 30. w obawie przed prześladowaniami władz. A jednocześnie groźby i naciski radykalnych zwolenników Komunistycznej Partii Zachodniej Białorusi na wsi zmuszały wielu chłopów do odrzucenia lektury umiarkowanej białoruskiej, chrześcijańsko-demokratycznej lub innej prasy, a pozostanie przy tytułach prosowieckich i komunistycznych. 
Prasa BChD-BZN mogła być postrzegana przez chłopów jako coś niezwykle wartościowego. W oczach mieszkańców wsi i miasteczek była rzadkim i pożądanym dobrem. Jej celem było nie tyle stworzenie wokół siebie kręgu czytelników, co członków „wspólnoty moralnej”. Za publiczne, a więc warte dyskusji uważane było wszystko, co budowało „wspólnotę moralną": białoruskie życie polityczne, czynniki społeczno-kulturowe, tożsamość narodowa, działalność BChD-BZN, Białoruskiego Instytutu Gospodarki i Kultury itd. Wszystko, co znajdowało się poza tym kręgiem, było ignorowane i nie trafiało na strony organów prasowych białoruskich chrześcijańskich demokratów. Jednocześnie gazety i czasopisma białoruskich chrześcijańskich demokratów wykorzystywały mechanizmy kultury oralnej i ustnego rozpowszechniania informacji.

$\mathrm{W}$ rozdziale drugim rozpatrzony został problem ewolucyjnego programu transformacji społecznej białoruskiego społeczeństwa w Polsce, wyrażany na łamach prasy BChD-BZN. Zbadano także aspekt darwinizmu społecznego, jako „dyskursu zagrożenia” w oczach białoruskich chłopów, i „ciemną" stronę postępu.

Konstruując dyskurs ewolucji jako program społecznej transformacji społeczeństwa białoruskiego w Polsce, chrześcijańskim demokratom niemal udało się uniknąć skrajności idei pesymistycznych i apokaliptycznej walki o „tysiącletnie Królestwo Boże". Element eschatologii był obecny w czymś innym: dotyczył obrazu przyszłej idealnej Białorusi, zbudowanej na sprawiedliwości i prawdzie. W takim właśnie kontekście miał się zmaterializować projekt nowoczesności BChD-BZN i wartości „wspólnoty moralnej”.

Prasa BChD-BZN była całkiem przekonująca dla swoich czytelników, członków „wspólnoty moralnej”, twierdząc, iż pokojowe zmiany społeczne są możliwe i konieczne. Jednak te idee, choć znane lokalnym elitom od XIX w., dotarły na Zachodnią Białoruś do masowego czytelnika wiejskiego z zupełnie innego kontekstu społeczno-kulturowego. Były to idee i koncepcje przedstawicieli klasy średniej miast. Zadanie intelektualnych i politycznych przywódców chrześcijańskich demokratów polegało na tym, aby dostosować dyskurs ewolucji i postępu do percepcji wiejskich czytelników.

Wydarzenia wojen i rewolucji lat 1914-1921 faktycznie zmusiły białoruskich chłopów do wejścia w kontakt z licznymi przedstawicielami innych krajów i narodów: żołnierzami, oficerami, urzędnikami, specjalistami, uczonymi itd. Prasa chrześcijańskich demokratów wykorzystała to doświadczenie do stworzenia obrazu idealnej przyszłości Białorusi, ucieleśnionej przez inne kraje i narody. Nowoczesność była zmienna, podobnie jak różne były opisy krajów, narodów i ruchów politycznych na łamach prasy BChD-BZN. Ale to właśnie doświadczenie lat wojen i rewolucji doprowadziło, na podstawie obserwacji tych samych 
zwolenników chrześcijańskich demokratów na wsi i w miasteczkach, do tego, że chłopi nie interesowali się ani ideami ewolucji, ani aktywnymi działaniami związanymi z programem $\mathrm{BChD}-\mathrm{BZN}$.

Okres 50 lat na dokonanie ewolucyjnych zmian w społeczeństwie białoruskim wykraczał poza wyobrażenie absolutnej większości chłopstwa. Natomiast sama ewolucja i postęp stały się celami zamiast tego, by być środkami do osiągnięcia celów. Wskazuje na to wątpliwość zawarta w tytule z końca 1938 r. „Jest postęp czy nie?”.

W rozdziale trzecim analizie poddano dyskurs dyscypliny czasu, jak również związane z nim wartości dobrego gospodarowania oraz wydajnych metod prowadzenia gospodarstwa i pracy. $\mathrm{W}$ odpowiednim podrozdziale poruszono kwestię prognoz dotyczących przyszłości, które wyłaniają się z korespondencji nadesłanych do gazet i czasopism BChD-BZN.

Dyskurs prasy chrześcijańsko-demokratycznej wyraźnie przeciwstawiał różne jakościowe formy spędzania czasu, przedstawiając opisy, od których zależała jego ocena moralna. Czarno-białe postrzeganie z jednej strony wysoko oceniało czytanie gazet i książek, dążenie do oświecenia, tworzenie (gdzie i kiedy było to możliwe) filii białoruskich organizacji gospodarczych i kulturalnych, a z drugiej - nisko oceniało nadużywanie alkoholu, palenie, gry karciane, rozrywki i antysemityzm.

W tym sensie szczególne zaniepokojenie wzbudzała młodzież, ponieważ stanowiła fizyczne ucieleśnienie przyszłości i jej wartości. Jednocześnie wymienione formy wykorzystania czasu mogły w rzeczywistości współistnieć w życiu poszczególnych młodych chłopów, którzy nie widzieli w tym żadnej sprzeczności.

Komuniści z powodu swojej quasi-religijnej wiary w mesjanistyczną rolę rewolucyjnej klasy robotniczej byli skłonni gardzić codziennością, uważaną za błahą w ich planach całkowitej przebudowy kultury i społeczeństwa poprzez ich faktyczne zniszczenie. Komuniści w swoich działaniach (ponieważ ich program ostro potępiał i negował religię i religijność) faktycznie nie różnicowali religii i polityki, które na poziomie kulturowym i historycznym są rzeczywiście mocno ze sobą powiązane. Jednak to właśnie białoruscy chrześcijańscy demokraci naprawdę głęboko i poważnie rozumieli związek religii i polityki, które starali się od siebie oddzielić, także na poziomie czasu. Dlatego wyznawali oni bardziej otwarte i zniuansowane podejście do rzeczywistości społecznej i kulturowej w Zachodniej Białorusi.

Niemniej BChD i jej prasa oferowały potencjalnie sprzeczny z chłopskiego punktu widzenia wariant stosunku do codzienności. Codzienność miała stać się zarówno czasem pracy, jak i prób, czasem bólu i cierpienia. To ostatnie uznawano 
za niesprawiedliwość. Podkreślano jednak, że Białoruś i Białorusini wzięli na siebie wszystkie cierpienia Europy w czasie poprzedniej wojny światowej, co pokazano na przykładzie kalendarza „Nasz Dom” („Наша Хата”) z 1920 r. Było to wyraźne nawiązanie do wizji Polski okresu romantyzmu jako Chrystusa, co nie dziwi z powodu znaczenia nadawanego przez białoruskich chrześcijańskich demokratów XIX wiekowi i jego dziedzictwu.

Jest tu również wyraźnie określony pogląd na cierpienia jako rodzaj symbolicznego kapitału. Ponieważ cierpień w różnych kulturach nie doświadcza się tylko dla nich samych, to stają się one ceną, jaką Białorusini muszą zapłacić za rozwój ewolucyjny.

Dyscyplina czasu, zaproponowana przez białoruskie pisma chrześcijańsko-demokratyczne, istniała $\mathrm{w}$ powiązaniu z projektem ewolucyjnego rozwoju społeczeństwa zachodniobiałoruskiego, podkreślała wagę intensywnych metod prowadzenia gospodarki rolnej, rozwoju sieci organizacji kulturalnych i gospodarczych. W ujęciu idealnym czas powinien zostać zaoszczędzony i racjonalnie wykorzystywany zarówno na poziomie poszczególnych Białorusinów, jak i na poziomie zbiorowym, wpływając zarówno na sferę prywatną, jak i publiczną, tworząc społeczność, w której czas należał do celów przyszłości, dyktującej modele zachowania.

Dyskurs dyscypliny czasu przeplatał się nie tylko z działalnością gospodarczą i kulturalną, ale wiązał się z lekturą białoruskich periodyków, literatury i in., tworząc swoistą syntezę wszystkich tych elementów, powiązanych przez projekt budowy nowoczesnego społeczeństwa białoruskiego według zasad, które BChD-BZN uznała za akceptowalne dla Białorusinów. Jednakże dyskurs ten, w warunkach braku istotnych zmian modernizacyjnych i urbanizacyjnych, pozostawał retoryką, która jedynie kreowała to, co samo w sobie stanowiło „industrializacyjne" oczekiwania społeczne, ale nie działała w nurcie pełnowymiarowych przemian.

Wprowadzenie kalendarzy białoruskich na wsi można uznać za wielki sukces kulturowy i ideologiczny chrześcijańskich demokratów przed 1939 r. W staraniach BChD-BZN i jej prasy można też dostrzec swoisty rodzaj „miękkiej” kolonizacji codzienności za pomocą dyscypliny czasu. Kalendarz był syntetycznym w swoich funkcjach i łączeniu w nim typów czasu społecznego (tradycyjnego i racjonalnego) narzędziem orientacji czasowej, które może być równie przydatne i skuteczne zarówno dla starszego przedwojennego, jak i powojennego młodego pokolenia.

Kalendarz, przy wszystkich ograniczeniach dyskursu dyscypliny czasu, pozostawał sukcesem białoruskich chrześcijańskich demokratów, ucieleśnieniem 
niedostrzegalnej ingerencji w życie codzienne dokonane przez intelektualistów i polityków w Wilnie. Kalendarz był nie tylko narzędziem orientacji w ruchu ku przyszłości, był elementem życia codziennego. Natomiast chłopi, wbrew pierwotnym nadziejom, na ogół nie byli skłonni myśleć o przyszłości, która była iluzoryczna lub mogła nadejść w odległej perspektywie. Bardziej zrozumiały był dla nich dzień dzisiejszy, codzienność.

Rozdział czwarty porusza problem stosunku wobec miasta i braku możliwości wypracowania jednoznacznego stosunku wobec niego. Ponieważ miasto samo w sobie uosabiało ambiwalentną naturę nowoczesności, której idealny wariant chcieli stworzyć członkowie „wspólnoty moralnej”, temat ten został rozpatrzony w trzech wymiarach (miasto jako dobro, miasto jak zło, miasto poza dobrem i złem).

W prasie chrześcijańsko-demokratycznej nie istniał integralny i wyidealizowany obraz miasta, nawet jeśli mowa o jego pozytywnych aspektach. To różne idee, różne tematy. Nie są one samodzielnymi wątkami, ale przeplatają się $\mathrm{z}$ innymi, niezwiązanymi bezpośrednio z miastem, koncepcjami drugiej połowy XIX i pierwszego ćwierćwiecza XX w. w ogólnoeuropejskiej, polskiej i rosyjskiej myśli i literaturze, kontekstach społeczno-kulturowych, pod których wpływem kształtował się stosunek białoruskich działaczy do nowoczesności.

Miasto, podobnie jak wieś, nie jest pustą kategorią dyskursywną. W rzeczywistości problem miasta w prasie BChD-BZN był interpretowany nie sam przez się, ale jako kwestia wyboru akceptowalnej wersji nowoczesności.

Miasto było ujmowane tylko w związku ze wsią. Mogły być sobie przeciwstawione, ale mogły też się uzupełniać. Nie można ich było rozdzielić. Estetyka artykułowała i podkreślała to poprzez posługiwanie się podstawowymi opozycjami kulturowymi, takimi jak „stałe - tymczasowe”, ,wysokie - niskie”, „prawdziwe - fałszywe”, „chaos - porządek”, „czyste - brudne”, „skromność - rozpusta”, „pracowitość - bezczynność" i in.

Podkreślano, że Białorusini mogli uosabiać symboliczną czystość, która nie miała nic wspólnego z rasową, dążenie do porządku, pokoju, szacunek dla tego, co stałe, a nie tymczasowe, szacunek dla historii i kapitału kulturowego. Estetyka była powołana do chronienia symbolicznych granic wspólnoty przed zagrożeniami. Miasto nie uosabiało przecież jednoznaczności, było zarówno miejscem ryzyka, jak i miejscem możliwości. Było ambiwalentne. Jednak dla zachodniobiałoruskich chłopów udział w ruchu narodowym i sympatyzowanie z BChD-BZN już stanowiły znaczne ryzyko.

Dopiero gdy mowa była o symbolach, wówczas miasto jako miejsce kościołów, cerkwi, pomników i miejsc ikonicznych nabierało dla chrześcijańskich 
demokratów jednoznacznie pozytywnego znaczenia. Było obecne jako łącznik czasów, jako dowód stałości, a nie tymczasowości.

Białoruskim chrześcijańskim demokratom nie podobała się materialna strona miasta, kapitalistyczna nowoczesność. Miasto, które istniało w ich wyobrażeniach, było niewidoczne, nieoczywiste dla innych obserwatorów. Działacze BChD-BZN szukali pastoralnej, idealnej, pozbawionej konfliktów i wad strony miasta. Aby ta wizja miasta i związane z nią znaczenia, które sobie wyobrażali, stały się rzeczywistością, ucieleśniły się, musiała nastąpić transformacja społeczna, modernizacja białoruskiego społeczeństwa. Ona z kolei domyślnie poruszała czynnik materialny i ekonomiczny, który wiązał się również z poszukiwaniem miejsca dla siebie w mieście, w nowoczesności. Same tylko symbole, historia, kapitał kulturowy nie wystarczały, aby urzeczywistnić zmiany społeczne.

Periodyki BChD-BZN chciały, aby białoruscy chłopi z północno-wschodnich województw II Rzeczypospolitej przenieśli się do miasta na ich warunkach, jednak trzeba było szukać kompromisu. Zamiast jednoznacznego potępienia materializmu, pieniądza jako zła, u schyłku okresu międzywojennego przyszło zrozumienie, że nie stanowi to bodźca do rozwoju białoruskiego ruchu narodowego. Konieczne było również zrewidowanie stosunku do tych grup, które postrzegano jako spolonizowane, dotknięte upadkiem moralnym czy kultem wartości materialnych.

Miasto jako ucieleśnienie ambiwalencji nowoczesności domagało się jako wartości świadomej ostrożności, która, mając na uwadze dominację negatywnych aspektów w postrzeganiu miasta, dostrzegała jednak jego konieczność, nieuchronność i związek ze wsią.

Rozdział piąty został poświęcony analizie problemu transformacji wybranych elementów kultury wiejskiej w symbole etniczne, które w „odpowiedni sposób” powinny ilustrować charakter narodowy „wspólnoty moralnej”. Ukazano także dyscyplinujący charakter samej koncepcji kultury jako warunku uczestnictwa we „wspólnocie moralnej”. Poruszono kwestię roli aktualizacji symboli etnicznych oraz zachęcania do zbierania pieśni i folkloru w mechanizmie przekształcenia chłopstwa Zachodniej Białorusi w klasę społeczną na wzór klas średnich Europy Zachodniej i Ameryce Północnej. Odwołano się też do przykładu chłopów w krajach Europy Środkowo-Wschodniej i bezpośrednich sąsiadów Białorusinów w Polsce, na Litwie itd.

Prasa BChD-BZN nie była wcale jedynym czynnikiem wpływającym na kulturę chłopską w okresie międzywojennym. Różne instytucje i struktury starały się regulować, ograniczać, represjonować i cenzurować pewne jej strony, aspekty lub elementy, jak to miało miejsce również w innych epokach. 
Ale zadanie BChD-BZN było w tym sensie nie tylko negatywne, ale także pozytywne. Rzeczywiście, aby stworzyć nowoczesną kulturę narodową, konieczne było również zastosowanie koncepcji dyscyplinarnej, która zracjonalizowałaby kulturę mieszkańców wsi i miasteczek. Wiązał się z tym zromantyzowany i wyidealizowany obraz kultury chłopskiej, ponieważ służył jako wzór dla transformacji kultury wiejskiej w kulturę nowoczesną. Część kultury wiejskiej zaczęto propagować jako symbole etniczne.

Prasa BChD-BZN przyczyniła się do powstania wśród swoich czytelników wizji zunifikowanego i ustandaryzowanego białoruskiego języka literackiego. Przyczyniła się ona także do pojawienia się wyobrażenia o jednolitym kompleksie symboli etnicznych poprzez utrwalanie folkloru i zwyczajów, tekstualizację i tekstową standaryzację pieśni i obrzędów, stymulowanie ich zapamiętywania i przyswajania już jako „nowych”. Symbole te świadczyły o unikalności i siłach witalnych Białorusinów, nawet po uwzględnieniu „społecznego darwinizmu słabych".

Jeśli symbole etniczne były jednoznacznie przypisywane pozytywnej sferze kultury, to niektóre ich aspekty i elementy były przez prasę chrześcijańskich demokratów oceniane negatywnie lub po prostu pomijane milczeniem. Jednocześnie z jednej strony zwolennicy chrześcijańskich demokratów na wsi i w miasteczkach pragnęli wykorzystać „wywrotowy” charakter kultury wiejskiej, nie prowokując represji i symbolicznie stawiając opór polskiej dominacji. Jednak $\mathrm{z}$ drugiej strony starali się kontrolować ten potencjał, ponieważ mógł on przecież przeszkodzić w budowaniu „moralnej wspólnoty”.

Część białoruskich chłopów mogła nadal nie podejrzewać, że zwykłe rzeczy codziennego chłopskiego użytku, święta, a nawet zajęcia rekreacyjno-rozrywkowe, które praktykowali w swojej miejscowości, mają znaczenie wychodzące poza ich wyobrażenia. Tym niemniej w Zachodniej Białorusi Białoruska Chrześcijańska Demokracja zdołała, grając według skrajnie niekorzystnych dla siebie reguł, przekonać zarówno część chłopstwa, jak i wykształconą część Białorusinów o wadze tradycyjnej kultury jako czegoś, co odróżnia ich od Polaków, a także przekonać do tego, że mogą być dumni z artefaktów i praktyk swojej kultury.

Rozumiana jako wartość, jako cenny zasób, kultura wiejska miała łączyć Białorusinów - katolików i prawosławnych. Zgodnie z planem działaczy BChD-BZN, podział wyznaniowy powinien być przezwyciężany poprzez integrację poziomą wzdłuż linii kultury i klasy, co pokazano w następnym rozdziale, ponieważ przynależność klasowa nie została tutaj całkowicie określona przez konflikt. W danej sytuacji klasę starano się budować na bazie kulturowej, a ta sama kultura chłopska miała stać się podstawą kultury narodowej. 
Tradycyjna kultura wiejska, kultura chłopska, nadal istniała także poza dyskursem prasowym BChD-BZN i dyskursem narodowym w ogóle według własnych praw. Mimo to dyskurs prasy białoruskich chrześcijańskich demokratów dawał części chłopów, którzy mieli z nim kontakt, wyobrażenie o tym, że otrzymują przynajmniej minimalną kontrolę nad swoją kulturą.

W ostatnim, szóstym rozdziale przeanalizowany został problem granic „wspólnoty moralnej”, sposoby jej wspierania i poszerzania, a także znaczenie roli tradycyjnej kultury wiejskiej i jej potencjału w tym procesie, podobnie jak wykorzystywania starych stereotypów dla podkreślania nowych różnic. Pokazano, jak w warunkach zamierania białoruskiego życia politycznego w II Rzeczypospolitej w drugiej połowie lat 30 . XX w. poszerzył się krąg grup, które postrzegano jako potencjalnie białoruskie i potencjalnych członków „wspólnoty moralnej”. Rozpatrzono także kwestię rozumienia chłopstwa jako klasy w prasie BChD-BZN.

„Wspólnota moralna” na łamach prasy chrześcijańskich demokratów miała dwa poziomy granic. Pierwszy dotyczył negatywnego aspektu tego, kim nie chcieli być przedstawiciele tej wspólnoty. Był on związany ze starymi wartościami, stereotypami i szerzej - z dziedzictwem ustnej kultury wiejskiej, a także sankcjami tradycyjnej wiejskiej opinii społecznej. Drugi był związany z czynnikami społeczno-kulturowymi i wartościami, które przenosili oni na wieś za pośrednictwem prasy BChD-BZN. Aby określić granice, potrzebne były standardy osądu i oceny, potrzebni byli ci, za którymi można lub nie należy podążać. Jeśli pierwotnie do połowy lat 20. XX w. takimi idealnymi przywódcami mogło być białoruskie duchowieństwo katolickie, przywódcy $\mathrm{BChD}$ i sami chłopi, to później okazywało się, że żadna grupa społeczna czy zawodowa nie spełniała wysokich wymagań przedstawicieli wspólnoty.

Wartości i moralność, za którymi opowiadała się BChD-BZN, wcale nie były $\mathrm{w}$ takim razie tradycyjne, przynajmniej $\mathrm{w}$ całości. Były one przywiązane do projektu nowoczesności chrześcijańskich demokratów. Obrazy pastoralne i kontr-pastoralne, korespondencje, które ostro krytykowały mieszkańców wsi czy miasteczek za ich zachowanie, pełniły dość dobrze zdefiniowaną funkcję: torowały drogę nowym wartościom poprzez wykorzystanie nostalgii i starych wartości.

Pomagało to ukryć nie tyle nawet nowe, co wręcz obce jeszcze chłopom wartości pod starymi. Istniały też punkty styczne starych i nowych wartości, jak na przykład pogląd na pracę chłopa i sam jego obraz. Przy czym obraz ten nie powstawał na wsi, ale był jej proponowany, a mieszkańcy wsi musieli się w nim „rozpoznać”. Nowe wartości i standardy osądu zostały zapożyczone z zewnątrz, 
jednak korespondenci aktywnie wykorzystywali je jako wiejskie. Pod koniec lat 30. XX w. zaczęli wskazywać na oczywisty aspekt tego problemu: nadmierną obfitość i nieadekwatność dla Białorusinów przykładów „innych”, czyli krajów, narodów czy ruchów politycznych wybranych jako pozytywny przykład lub model dla Białorusinów.

Stare wartości i te same stereotypy (jak w przypadku „panów”, „państwa” itd.) zostały zrównoważone lub zneutralizowane przez pozytywne przykłady z przeszłości i modele nowoczesności tego samego polskiego społeczeństwa, dlatego obraz Polski i Polaków nie ograniczał się do „panów” choć ponownie należy zauważyć, że podział dyskursu na dwa poziomy (high brow i low brow) utrzymywał się w prasie BChD-BZN aż do 1939 r.

Mimo to policjanci, sekwestratorzy, urzędnicy, nauczyciele i propolsko nastawieni przedstawiciele duchowieństwa katolickiego i prawosławnego nie cieszyli się poparciem chłopskich korespondentów, częściej spotykali się z potępieniem. Jednak to raczej motywowało redaktorów i przywódców do podjęcia przed wybuchem II wojny światowej próby poszerzenia „wspólnoty moralnej” o mieszczan i przedstawicieli drobnej szlachty, aby wyjść poza czarno-biały obraz rzeczywistości społecznej i opozycji binarnych.

Reasumując, czynniki społeczno-kulturowe odgrywały zasadniczą rolę w kształtowaniu się „wspólnoty moralnej” na łamach prasy BChD-BZN, a prasa ta miała większe znaczenie dla formułowania ideologii Białoruskiej Chrześcijańskiej Demokracji niż dokumenty polityczne, programy i odezwy przywódców na forach politycznych. Te czynniki wyznaczały granice „wspólnoty moralnej”, która nadawała projektowi nowoczesności białoruskich chrześcijańskich demokratów charakter zbiorowy. Do rozumienia pojęcia nowoczesności w prasie BChD-BZN przenikały z jednej strony sentymentalne i romantyczne wyobrażenia wsi i chłopów, a z drugiej - wyobrażenia o przyjściu „tysiącletniego Królestwa Bożego" prawdy i sprawiedliwości.

„Wspólnota moralna” pozostawała otwarta na przedstawicieli chłopstwa i innych warstw społecznych, a także na „innego", ponieważ to inne kultury, kraje i narody zapewniały i dostarczały modele budowania nowoczesnego społeczeństwa. Czynniki społeczno-kulturowe warunkowały powstanie nowoczesnego społeczeństwa. Włączanie się we wspólnotę wiązało się z koniecznością uznania ich nadrzędnej roli, aby przetrwać w warunkach nowoczesnej polityki, gospodarki i kultury.

W perspektywie badawczej warto wskazać na konieczność przeprowadzenia dalszych badań porównawczych międzywojennej prasy zachodniobiałoruskiej reprezentującej różne nurty ideologiczne i wykorzystania na jej łamach 
ustnej kultury wiejskiej. Bardzo interesujące byłyby również badania porównawcze na materiale polskiej i litewskiej prasy XIX-wiecznej i z pierwszej połowy XX w.

Aliaksandr Paharely (ur. 1982 r.) - doktor nauk humanistycznych z zakresu historii. Studia doktoranckie ukończył w Instytucie Slawistyki Polskiej Akademii Nauk. Bada problemy modernizacji i tożsamości białoruskiej w Polsce międzywojennej oraz dzieje białoruskiego ruchu narodowego w XIX i XX w. Jest autorem ponad trzydziestu publikacji naukowych.

e-mail: mbv.mancunian@gmail.com 